Western University

Scholarship@Western

Aboriginal Policy Research Consortium International (APRCi)

2003

\title{
Chronic Disease Coverage in Canadian Aboriginal Newspapers
}

Laurie Hoffman-Goetz

Follow this and additional works at: https://ir.lib.uwo.ca/aprci

Citation of this paper:

Hoffman-Goetz, Laurie, "Chronic Disease Coverage in Canadian Aboriginal Newspapers" (2003). Aboriginal Policy Research Consortium International (APRCi). 294.

https://ir.lib.uwo.ca/aprci/294 
This article was downloaded by: [University of Western Ontario]

On: 16 December 2012, At: 07:36

Publisher: Taylor \& Francis

Informa Ltd Registered in England and Wales Registered Number: 1072954 Registered office: Mortimer House, 37-41 Mortimer Street, London W1T 3J H, UK

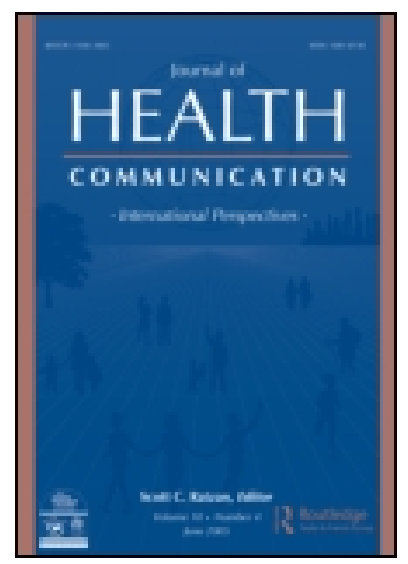

\title{
J ournal of Health Communication: International Perspectives
}

Publication details, including instructions for authors and subscription information:

http:// www. tandfonline.com/loi/ uhcm20

\section{Chronic Disease Coverage in Canadian Aboriginal Newspapers}

\author{
LAURIE HOFFMAN-GOETZ ${ }^{a}$, CHARLENE SHANNON ${ }^{b} \&$ J UANNE N. \\ CLARKE $^{\mathrm{C}}$ \\ a Department of Health Studies and Gerontology, University of \\ Waterloo, Waterloo, Ontario, Canada \\ ${ }^{\mathrm{b}}$ Department of Kinesiology, University of New Brunswick, \\ Fredericton, New Brunswick, Canada \\ ' Department of Sociology, Wilfrid Laurier University, Waterloo, \\ Ontario, Canada \\ Version of record first published: 02 Feb 2011.
}

To cite this article: LAURIE HOFFMAN-GOETZ, CHARLENE SHANNON \& J UANNE N. CLARKE (2003): Chronic Disease Coverage in Canadian Aboriginal Newspapers, J ournal of Health Communication: International Perspectives, 8:5, 475-488

To link to this article: http:// dx. doi.org/ 10.1080/ 10810730390233299

\section{PLEASE SCROLL DOWN FOR ARTICLE}

Full terms and conditions of use: http://www.tandfonline.com/page/terms-and-conditions

This article may be used for research, teaching, and private study purposes. Any substantial or systematic reproduction, redistribution, reselling, loan, sub-licensing, systematic supply, or distribution in any form to anyone is expressly forbidden.

The publisher does not give any warranty express or implied or make any representation that the contents will be complete or accurate or up to date. The accuracy of any instructions, formulae, and drug doses should be independently verified with primary sources. The publisher shall not be liable for any loss, actions, claims, proceedings, demand, or costs or damages whatsoever or howsoever caused arising directly or indirectly in connection with or arising out of the use of this material. 


\title{
Chronic Disease Coverage in Canadian Aboriginal Newspapers
}

\section{LAURIE HOFFMAN-GOETZ}

\author{
Department of Health Studies and Gerontology, University of Waterloo, \\ Waterloo, Ontario, Canada
}

\section{CHARLENE SHANNON}

Department of Kinesiology, University of New Brunswick, Fredericton, New Brunswick, Canada

\section{JUANNE N. CLARKE}

Department of Sociology, Wilfrid Laurier University, Waterloo, Ontario, Canada

\begin{abstract}
Purpose: To determine the volume and focus of articles on four chronic diseases in newspapers targeting First Nations, Métis, and Inuit in Canada.

Methods: From a sampling frame of 31 Aboriginal newspapers published in English from 1996-2000, 14 newspapers were randomly selected allowing for national and regional representation. Newspaper archives were searched at the National Library of Canada and articles selected if the disease terms cancer, cardiovascular disease, diabetes, or HIV/AIDS appeared in the headline, or in the first or last paragraph of the article. Articles were coded for inclusion of mobilizing information (local, distant, unrestricted, not specified, none) and content focus (scientific, human interest, commercial, other). Cancer articles were categorized by tumor site specificity. Data were analyzed by frequency, cross tabulations, and chi-square analysis.

Results: Of 400 chronic disease articles, there were significantly more articles on HIV/AIDS (167 or $41.8 \%)$ and diabetes (135 or $33.8 \%)$ and few articles on cancer (56 or $14 \%$ ) and cardiovascular disease (30 articles or $7.5 \%)(p<0.001)$. Slightly more than one third $(36.5 \%)$ of the articles contained mobilizing information to enable readers to take further health action. Mobilizing information was virtually absent from cardiovascular (7/30 or $23 \%)$ and diabetes (29/135 or $21.5 \%)$ articles. Site specific cancer coverage differed significantly from chance $(p<0.001)$ with $41 \%$ of the articles on breast cancer and no articles on lung or colorectal cancers.

Interpretation: Given the burden of tobacco-related cardiovascular disease and cancer in Canadian Aboriginal people, the lack of coverage and limited mobilizing information in ethnic newspapers are a missed opportunity for health promotion.
\end{abstract}

This research was supported by a grant from the Social Sciences and Humanities Research Council of Canada. The authors gratefully acknowledge comments and suggestions on the manuscript from Dr. P. Smith and the help of the librarians at the National Library of Canada.

Address correspondence to Laurie Hoffman-Goetz, Ph.D., M.P.H., Department of Health Studies and Gerontology, BMH 2321, Faculty of Applied Health Sciences, University of Waterloo, Waterloo, ON, Canada N2L 3G1. E-mail: lhgoetz@healthy.uwaterloo.ca 


\section{Introduction}

People obtain health and medical information from multiple sources including physicians, nurses, family, friends, telephone hotlines, the workplace, television, radio, newspapers, magazines, pamphlets, and the Internet. Physicians and health care providers are often ranked by the public as the most important channel for health information but they may not in fact be the most important source of such information. Research has shown television and newspapers to be the most frequently cited source of cancer information (James, James, Davies, Harvey, \& Tweddle, 1999), diet, exercise and health information (Hofstetter, Schultze, \& Mulvihill, 1992), and genetic information (Frewer \& Shepherd, 1994). Although health professionals were cited as the preferred source of cancer related information, more respondents actually received cancer information from the media than from health professionals (Johnson \& Meischke, 1991). This may be due to the fact that while most people visit their physician sporadically and for very specific purposes (e.g., when individuals are ill), they are exposed to the mass media on a daily basis. People rely on newspapers and television current affairs over research publications, government pamphlets, consumer organization leaflets, and friends (Frewer \& Shepherd, 1994). Their interest in new medical discoveries in the news is greater than their interest in sports and politics (Durant, Evans, \& Thomas, 1989).

Although mass media inform the public about health risks, it may not be balanced proportional to the leading causes of population morbidity and mortality. For example, Hoffman-Goetz, Gerlach, Marino, and Mills (1997), Hoffman-Goetz and MacDonald (1999), and Gerlach, Marino, and Hoffman-Goetz (1997) have shown an overemphasis on the reporting of breast cancer in magazines targeting African American women and white North American women and an underreporting of risks for lung cancer, the leading cause of cancer death in North American women. This promotion of awareness of one disease condition over other more prevalent diseases may have an adverse impact on risk perceptions (Gottlieb, 2001).

The mass media may also fail to capture disparities in health among subpopulations, minorities, and underserved groups. For example, in Canada, Aboriginal populations (First Nations, Métis, and Inuit) have higher morbidity and mortality rates than the general population (Young, 1993; Young, Moffatt, \& O'Neil, 1993). Approximately onethird of the Aboriginal population in Canada, aged 15 and older, have been informed that they have a chronic physical illness (MacMillan, MacMillan, Offord, \& Dingle, 1996). Prevalence of diabetes, HIV/AIDS, cardiovascular disease, hypertension, and cancer are higher than in the general population. Results of the 1991 Aboriginal Peoples Survey indicate diabetes mellitus prevalence rates of $6.4 \%$ for First Nations people, $5.3 \%$ for Métis people and $1.9 \%$ for Inuit people, as compared to the Canadian population average of $3.1 \%$ (Health Canada, 2000a). Although prevalence data must be viewed cautiously because of under-enumeration of Aboriginal peoples, tobacco use, a risk factor for cardiovascular disease and cancer, is substantially higher than in the general population (WUNSKA \& SIFC, 1997). The evidence is similar across other North American jurisdictions; higher age-adjusted incidence and mortality rates for lung cancer characterize other aboriginal populations (Burhansstipanov \& Dresser, 1994; Ehrsam, Lanier, Holck, $\&$ Sandidge, 2001). If information in the general media does not capture disparities in specific groups, perhaps these subgroups are getting their health information in culturespecific publications. This is not known.

Even when information on disease conditions is presented, the mass media often provide only information and fail to provide follow-up or mobilizing information to enable behavioral actions (Fink et al., 1978; MacDonald \& Hoffman-Goetz 2001). 
Information alone cannot change behavior. However, when health information is linked to community resources, individual and collective actions can lead to healthier people and communities (Clift \& Freimuth, 1995). Intentions to perform detection behaviors were stronger after receiving a media message with performance information allowing greater self-efficacy than after a merely information-based message (Miller \& Millar, 1998). Lack of mobilizing information in the media may be more an issue in communities that lack infrastructure and community resources than in communities with access to support services.

The purpose of this study was to describe the volume and type of coverage of cancer, diabetes, cardiovascular disease, and HIV/AIDS in newspapers serving the Canadian Aboriginal population. We were interested in determining whether the amount of coverage of chronic diseases in newspapers reflected available population statistics (prevalence, incidence, or mortality rates) associated with those diseases. A second objective was to determine the type and extent of mobilizing information about cancer, heart disease, diabetes, and HIV/AIDS embedded in the articles. Because many of the Aboriginal peoples live in rural and/or northern remote locations, mobilizing information which does is not easily enable health action or intention to action may be disregarded, not attended to, or serve as a barrier.

\section{Methods}

A list of Aboriginal (First Nations, Métis, Inuit) newspapers published within Canada was compiled from a variety of sources: the Aboriginal Multimedia Society (http:// www.ammsa.com/ams/amscanadapubs.htmlanchor167885), the Canadian Advertising Rates and Data (CARD) publication for Ethnic Markets Winter/Spring 2002, and the Canadian Aboriginal Media Cooperative (http://www.camcop.com/members/html. Additional Aboriginal newspapers were identified from the Internet and hand-searches of published papers (Demay, 1993). A total of 41 Canadian Aboriginal newspapers was identified (Table 1) and from this sampling frame, items were excluded if not written in English, not published continuously from 1996-2000, published less than four times per year, target market was not Aboriginal peoples, or the publication was inactive. Of the 31 remaining newspapers, a sampling fraction of approximately $40 \%$ was used with the inclusion of at least one newspaper from each province or territory, with the exception of New Brunswick, Prince Edward Island, and Newfoundland/Labrador for which there were no Aboriginal newspapers which met the inclusion criteria. If the identified newspaper was not available at the National Library of Canada, an alternate for that province or territory was chosen. The following newspapers were included in this study: Windspeaker, Micmac-Maliseet Nation News, Eastern Door, Wawatay News, Tekawennake, Wikwemikong News, Indian Life, Saskatchewan Sage, Alberta Native News, Western Native News, Ha-Shilth-Sa, Secwepemc News, News North, and Nunastsiaq News.

Newspapers were searched for appropriate articles for 1996-2000 inclusive. Articles were selected if the terms cancer, heart disease, cardiovascular disease, hypertension, stroke, diabetes, or HIV/AIDS appeared in the headline, or in the first or last paragraph of the article. This search strategy has been used elsewhere (MacDonald \& Hoffman-Goetz, 2001). With the exception of Windspeaker, none of the Aboriginal newspapers was available on searchable databases (Canadian Newsdisc or Lexis-Nexis); there were no Aboriginal newspapers indexed in searchable databases for the five-year time period under study. Disease mentions in non-health articles (e.g., obituaries, comics, and recipes) were excluded as these do not reflect editorial policy. For analysis purposes, cardiovascular disease included ischemic heart disease, hypertension, and neurovascular disease (stroke). 
TABLE 1 Canadian Aboriginal Newspapers Identified in Sampling Frame

\begin{tabular}{|c|c|c|c|c|}
\hline Newspaper & $\begin{array}{l}\text { Province of } \\
\text { Publication }\end{array}$ & $\begin{array}{c}\text { Publisher; } \\
\text { Community Served }\end{array}$ & Language & $\begin{array}{l}\text { Circulation } \\
\text { (estimate)* }\end{array}$ \\
\hline Windspeaker & National & $\begin{array}{c}\text { Aboriginal Multimedia } \\
\text { Society; Canadian } \\
\text { Aboriginal Peoples }\end{array}$ & English & 18000 \\
\hline $\begin{array}{l}\text { FirstNations } \\
\text { Drum }\end{array}$ & National & $\begin{array}{c}\text { Canadian Aboriginal } \\
\text { Peoples }\end{array}$ & English & - \\
\hline $\begin{array}{l}\text { Native } \\
\text { Journal }\end{array}$ & National & First Nations of Canada & $\begin{array}{l}\text { English and } \\
\text { French }\end{array}$ & 10000 \\
\hline $\begin{array}{l}\text { First } \\
\quad \text { Perspective }\end{array}$ & National & $\begin{array}{c}\text { Canadian Aboriginal } \\
\text { Peoples }\end{array}$ & English & 10000 \\
\hline $\begin{array}{l}\text { Kinatuinamot } \\
\text { Ilengajuk }\end{array}$ & Labrador & Okalakatiget Society & - & - \\
\hline $\begin{array}{l}\text { Micmac- } \\
\text { Maliseet } \\
\text { Nation } \\
\text { News }\end{array}$ & Nova Scotia & $\begin{array}{l}\text { Mi'kmaq-Maliseet } \\
\text { Nations News } \\
\text { Association; Mi'kmac- } \\
\text { Maliseet Nations in } \\
\text { Atlantic Canada, } \\
\text { Quebec, and Maine }\end{array}$ & $\begin{array}{l}\text { English, } \\
\text { French, } \\
\text { Mi'kmac, } \\
\text { Maliseet }\end{array}$ & 3500 \\
\hline Indian Times & Quebec & Akwesasne Community & - & 3000 \\
\hline The Nation & Quebec & $\begin{array}{c}\text { Beesum Communications; } \\
\text { James Bay Cree }\end{array}$ & $\begin{array}{c}\text { English and } \\
\text { Cree }\end{array}$ & 6200 \\
\hline Eastern Door & Quebec & $\begin{array}{l}\text { K. Deer (Kahnawake } \\
\text { Mohawk Association) }\end{array}$ & $\begin{array}{l}\text { English and } \\
\text { Mohawk }\end{array}$ & 2700 \\
\hline $\begin{array}{l}\text { Anishnabek } \\
\text { News }\end{array}$ & Ontario & $\begin{array}{l}\text { Wikwemikong } \\
\text { Development } \\
\text { Commission }\end{array}$ & English & 5000 \\
\hline $\begin{array}{l}\text { Manitoulin } \\
\text { Expositor }\end{array}$ & Ontario & $\begin{array}{l}\text { First Nations of } \\
\text { Manitoulin Island }\end{array}$ & English & 5500 \\
\hline $\begin{array}{l}\text { Métis } \\
\text { Voyageur }\end{array}$ & Ontario & $\begin{array}{c}\text { Métis communities of } \\
\text { Ontario }\end{array}$ & $\begin{array}{c}\text { English and } \\
\text { French ? }\end{array}$ & 5000 \\
\hline $\begin{array}{l}\text { Turtle Island } \\
\text { News }\end{array}$ & Ontario & Six Nations & English & 10000 \\
\hline $\begin{array}{l}\text { Wawatay } \\
\text { News }\end{array}$ & Ontario & $\begin{array}{l}\text { Sioux Lookout-Wawatay } \\
\text { Native Communications }\end{array}$ & $\begin{array}{l}\text { English, } \\
\text { Cree, and } \\
\text { Ojibway }\end{array}$ & 8400 \\
\hline Tekawennake & Ontario & $\begin{array}{c}\text { Woodland Indian Cultural } \\
\text { Educational Centre/Six } \\
\text { Nations Reserve }\end{array}$ & English & 2050 \\
\hline $\begin{array}{l}\text { Wikwemikong } \\
\text { (Wiky) } \\
\text { News }\end{array}$ & Ontario & $\begin{array}{l}\text { Wikwemikong Unceded } \\
\text { Indian Reserve }\end{array}$ & English & 1000 \\
\hline Weetamah & Manitoba & - & - & 5000 \\
\hline Natotawin & Manitoba & - & - & 2500 \\
\hline
\end{tabular}


TABLE 1 Continued

\begin{tabular}{|c|c|c|c|c|}
\hline Newspaper & $\begin{array}{l}\text { Province of } \\
\text { Publication }\end{array}$ & $\begin{array}{c}\text { Publisher; } \\
\text { Community Served }\end{array}$ & Language & $\begin{array}{l}\text { Circulation } \\
\text { (estimate)* }\end{array}$ \\
\hline The Drum & Manitoba & $\begin{array}{c}\text { Taiga Communications; } \\
\text { Brokenhead Ojibway } \\
\text { Nation }\end{array}$ & English & 7000 \\
\hline $\begin{array}{l}\text { Thunder } \\
\text { Voice }\end{array}$ & Manitoba & - & English & 20000 \\
\hline $\begin{array}{l}\text { Grassroots } \\
\text { News }\end{array}$ & Manitoba & - & English & 20000 \\
\hline Indian Life & Manitoba & $\begin{array}{l}\text { Intertribal Christian } \\
\text { Communications; First } \\
\text { Nations Communities } \\
\text { of Manitoba }\end{array}$ & English & - \\
\hline $\begin{array}{l}\text { Eagle Feather } \\
\text { News }\end{array}$ & Saskatchewan & - & English & 8000 \\
\hline $\begin{array}{l}\text { The } \\
\text { Indigenous } \\
\text { Times }\end{array}$ & Saskatchewan & Aboriginal Times & English & 10000 \\
\hline Newbreed & Saskatchewan & $\begin{array}{c}\text { Métis Nation of } \\
\text { Sakatchewan }\end{array}$ & English & - \\
\hline $\begin{array}{l}\text { Saskatchewan } \\
\text { Sage }\end{array}$ & Saskatchewan & $\begin{array}{l}\text { Aboriginal Multimedia } \\
\text { Society of Alberta; } \\
\text { Métis and First Nations } \\
\text { in Saskatchewan }\end{array}$ & English & 7100 \\
\hline $\begin{array}{l}\text { Alberta } \\
\text { Sweetgrass }\end{array}$ & Alberta & $\begin{array}{l}\text { Aboriginal Multimedia } \\
\text { Society of Alberta; } \\
\text { Métis and First Nations } \\
\text { in Alberta }\end{array}$ & English & 7000 \\
\hline Kainai News & Alberta & Indian News Media & English & - \\
\hline $\begin{array}{l}\text { Alberta } \\
\text { Native } \\
\text { News }\end{array}$ & Alberta & $\begin{array}{c}\text { Alberta Native News; First } \\
\text { Nations, Métis } \\
\text { Communities in } \\
\text { Alberta, B.C., } \\
\text { Manitoba, Ont., } \\
\text { Western Arctic and } \\
\text { Nunavut }\end{array}$ & English & 14000 \\
\hline Kahtou News & $\begin{array}{l}\text { British } \\
\text { Columbia }\end{array}$ & $\begin{array}{c}\text { K'Watamus Publishing; } \\
\text { B.C. First Nations }\end{array}$ & English & 5000 \\
\hline $\begin{array}{c}\text { Ktuqcqakyam } \\
\text { Newsletter }\end{array}$ & $\begin{array}{l}\text { British } \\
\text { Columbia }\end{array}$ & - & - & - \\
\hline Raven's Eye & $\begin{array}{l}\text { British } \\
\text { Columbia }\end{array}$ & $\begin{array}{l}\text { Aboriginal Multimedia } \\
\text { Society; Aboriginal } \\
\text { Communities in B.C. } \\
\text { and Yukon }\end{array}$ & English & 7700 \\
\hline
\end{tabular}


TABLE 1 Continued

\begin{tabular}{|c|c|c|c|c|}
\hline Newspaper & $\begin{array}{l}\text { Province of } \\
\text { Publication }\end{array}$ & $\begin{array}{c}\text { Publisher; } \\
\text { Community Served }\end{array}$ & Language & $\begin{array}{l}\text { Circulation } \\
\text { (estimate)* }\end{array}$ \\
\hline $\begin{array}{l}\text { Western } \\
\text { Native } \\
\text { News }\end{array}$ & $\begin{array}{l}\text { British } \\
\text { Columbia }\end{array}$ & Western Native News & English & 10000 \\
\hline Ha-Shilth-Sa & $\begin{array}{l}\text { British } \\
\text { Columbia }\end{array}$ & $\begin{array}{c}\text { Nuu-Chah-Nulth Tribal } \\
\text { Council }\end{array}$ & English & 3500 \\
\hline $\begin{array}{l}\text { Secwepemc } \\
\text { News }\end{array}$ & $\begin{array}{l}\text { British } \\
\text { Columbia }\end{array}$ & $\begin{array}{l}\text { Secwepemc Cultural } \\
\text { Education Society }\end{array}$ & English & 2500 \\
\hline $\begin{array}{l}\text { Innuvik } \\
\text { Drum }\end{array}$ & $\begin{array}{l}\text { Northwest } \\
\text { Territories }\end{array}$ & $\begin{array}{c}\text { Northern News Services; } \\
\text { Gwich'in, Métis and } \\
\text { Inuvialuit people of } \\
\text { Beaufort Delta region }\end{array}$ & English & 1500 \\
\hline $\begin{array}{r}\text { Kivalliq } \\
\text { News }\end{array}$ & $\begin{array}{l}\text { Northwest } \\
\text { Territories }\end{array}$ & $\begin{array}{c}\text { Northern News Services; } \\
\text { First Nations of } \\
\text { Keewatin region }\end{array}$ & $\begin{array}{c}\text { English and } \\
\text { Inukitut }\end{array}$ & 1400 \\
\hline $\begin{array}{l}\text { Deh Cho } \\
\text { Drum }\end{array}$ & $\begin{array}{l}\text { Northwest } \\
\text { Territories }\end{array}$ & $\begin{array}{l}\text { Northern News Services; } \\
\text { First Nations of Deh } \\
\text { Cho region including } \\
\text { Slavey and Métis } \\
\text { people }\end{array}$ & English & 1150 \\
\hline News North & $\begin{array}{l}\text { Northwest } \\
\text { Territories }\end{array}$ & $\begin{array}{l}\text { Northern News Services; } \\
\text { Dene, Métis and Inuit } \\
\text { communities of NWT }\end{array}$ & English & 11000 \\
\hline Tusaayaksat & $\begin{array}{l}\text { Western } \\
\text { Northwest } \\
\text { Territories }\end{array}$ & $\begin{array}{c}\text { Inuvialuit of Mackenzie } \\
\text { Delta }\end{array}$ & $\begin{array}{l}\text { English and } \\
\text { Inuvialuk- } \\
\text { tun }\end{array}$ & 1200 \\
\hline $\begin{array}{l}\text { Nunatsiaq } \\
\text { News }\end{array}$ & Nunavut & Nortext Publishing & $\begin{array}{c}\text { English and } \\
\text { Inuktitut }\end{array}$ & 8000 \\
\hline
\end{tabular}

*Circulation numbers are estimates for 2001 based upon data reported in CARD, Aboriginal Multimedia Society, and personal communication with publisher. Note: - in a column indicates no information available.

Each article was coded for occurrence and type of mobilizing information (contact name, phone number, address, website, and agency) to enable follow-up health action. If mobilizing information was provided, specificity was recorded as local (e.g., telephone number within community area code, provincial postal code), distant (e.g., telephone number or address in another province or out of country), unrestricted (e.g., URL or tollfree number), and not specified (e.g., name of agency, organization, or individual but without specific contact details).

Articles were classified as scientific/informative or anecdotal/human interest. To be categorized as scientific, the article had $>75 \%$ of the total number of paragraphs (or sentences within a paragraph) on scientific findings or studies or about risk factors (e.g., new diabetes statistics; risk factors for heart attack) or with the goal of informing the reader to enhance self-efficacy (e.g., how to conduct a breast self exam). Articles which did not meet this criterion were classified as personal story/anecdotal (e.g., an individual's experience living with AIDS) (MacDonald \& Hoffman-Goetz, 2001). Articles with 
an equal coverage of scientific findings and human interest were classified as both. Articles which focused on fund-raising or product promotions were classified as other.

Cancer articles were further categorized as general or site specific using categories of common cancers identified by the U.S. National Cancer Institute. When an article discussed more than one cancer (e.g., breast and cervical), this was coded as multiple sites. General cancer articles included topics such as the role of fiber in reducing cancer risk or the importance of vitamins in fighting cancer.

Articles were coded independently by researchers involved in this study. Where discrepancies occurred in coding, these were discussed until consensus agreement was reached. The consensus coding was then used in the analysis and informed future coding. Articles were analyzed as frequencies, cross-tabulations, and chi-square $\left(\chi^{2}\right)$ using SPSS, version 10 . For all tests, the $p$ value was set at 0.05 .

\section{Results}

There were a total of 400 articles on cancer, cardiovascular disease, diabetes mellitus, and HIV/AIDS obtained from the 14 Aboriginal newspapers over the time frame 1996-2000. The greatest number of articles was about HIV/AIDS ( $n=167$ or $41.8 \%$ ), followed by diabetes $(n=135$ or $33.8 \%)$ and cancer $(n=56$ or $14 \%)$. The number of cardiovascular disease articles was low with only $30(7.5 \%)$ published in five years. The distribution of chronic disease coverage differed significantly from that expected by chance alone $\left(\chi_{\mathrm{df}(3)}^{2}=227, p<0.001\right)$. When the number of disease articles was expressed as a density (number of articles/1000 pages of newsprint) there were an average ( \pm 1 standard error) of 7.1 $\pm 2.6,6.0 \pm 1.5,2.0 \pm 0.6$, and $0.8 \pm 0.3$ articles/1000 pages for HIV/AIDS, diabetes, cancer, and cardiovascular disease, respectively.

Slightly more than one-third $(36.5 \%)$ of the articles contained mobilizing information which could enable or facilitate further health information seeking or health actions. Mobilizing information was evident in 21.5\% (29/135) of diabetes articles, $23 \%(7 / 30)$ of cardiovascular disease articles, $41 \%$ (23/56) of cancer articles, and 51.5\% (86/167) of HIV/AIDS articles. Figure 1 shows the type of mobilizing information available (i.e., local, distant, unrestricted) within each of these disease categories. There was significantly more mobilizing information available locally than through other jurisdictions. Of the 23 cancer articles with mobilizing information, more than half $(52.2 \%$ or 12 articles) were on breast cancer. There was no mobilizing information for articles on prostate, cervical, or ovarian cancers.

There was little change in the total number of articles (cancer, cardiovascular disease, diabetes, HIV/AIDS) between 1996 and $2000\left(\chi_{\mathrm{df}(4)}^{2}=7.38, p=\right.$ n.s. $)$, ranging from a high of 91 articles in 1998 to a low of 62 articles in 2000. The majority of articles published on these chronic diseases were written to inform about the science (risk factors, prevention options, treatment modalities) $(218 / 400$ or $54.5 \%)$, with fewer stories of a personal nature $(55 / 400$ or $13.8 \%)$. A large proportion of the articles focused on news about community fund-raising events or commercial products (109/400 or $27.3 \%)$. There were few articles that overlapped more than one focus category (classified as scientific and human interest, $18 / 400$ or $4.5 \%$ ). The focus of the articles differed as a function of the disease type, with greater human interest coverage about HIV/AIDS (69.1\%) compared with the other disease conditions ( $23.6 \%$ for cancer, $7.3 \%$ for diabetes mellitus). There were no human interest stories about cardiovascular disease.

Cancer coverage was further analyzed by tumor site specificity. Table 2 shows the number of cancer articles by site for all newspapers included in this study across years 


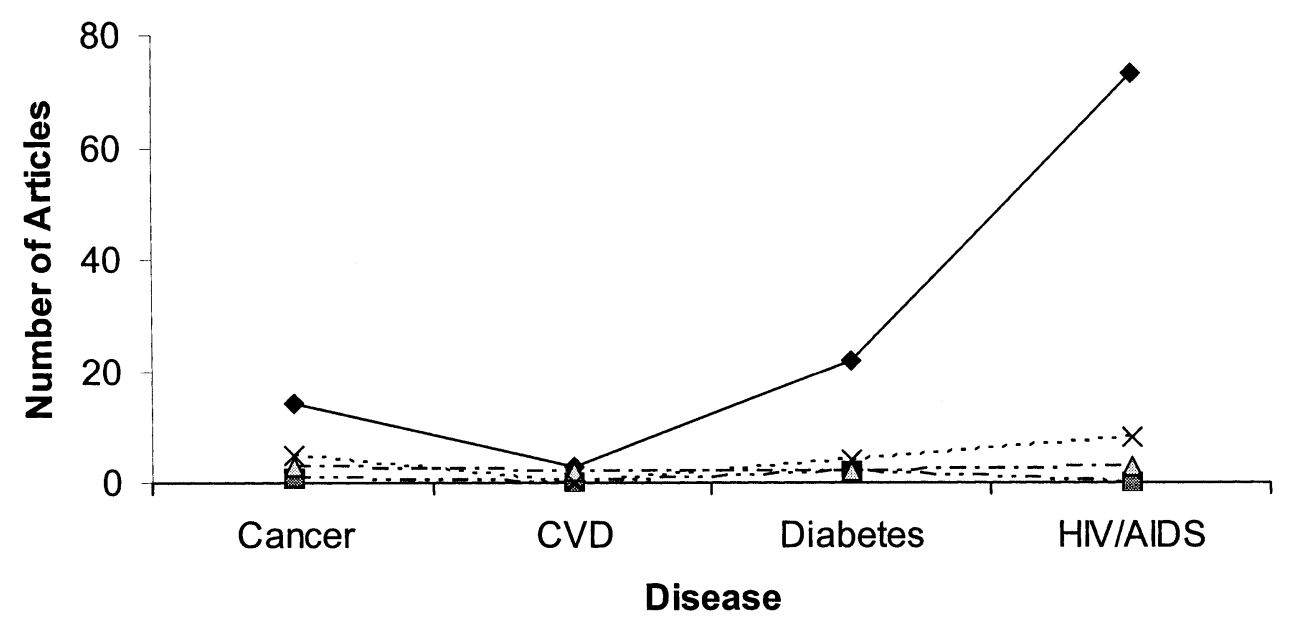

$\longrightarrow-$ Local $-\cdot-\cdot \cdot$ Not Specified $-\cdot \Delta \cdot-$ Distant $\cdots \times \cdot \cdot$ Unrestricted

FIGURE 1 Types of mobilizing information found in cancer, diabetes, heart disease and HIV/AIDS articles in Aboriginal newspapers in Canada, 1996-2000.

TABLE 2 Types of Cancers Covered in 14 Aboriginal Newspapers, 1996-2000

\begin{tabular}{|c|c|c|c|c|}
\hline $\begin{array}{l}\text { Type of } \\
\text { Cancer }\end{array}$ & $\begin{array}{l}\text { Number of } \\
\text { Cancer } \\
\text { Articles in } \\
\text { Aboriginal } \\
\text { Newspapers, } \\
\text { 1996-2000 }\end{array}$ & $\begin{array}{c}\text { Age- } \\
\text { Standardized } \\
\text { Mortality Rate } \\
\text { per 100,000; } \\
\text { Canada, 1997 }\end{array}$ & $\begin{array}{c}\text { Age- } \\
\text { Standardized } \\
\text { Mortality Rate } \\
\text { per 100,000; } \\
\text { Nunavut, } \\
\text { 1993-1997 }\end{array}$ & $\begin{array}{c}\text { Age- } \\
\text { Standardized } \\
\text { Mortality Rate } \\
\text { per 100,000; } \\
\text { N.W.T., } \\
\text { 1993-1997 }\end{array}$ \\
\hline Breast & 23 & 27 (†) & - & - \\
\hline Leukemia & 9 & $8(\widehat{0}) ; 5$ (우) & - & - \\
\hline Melanoma & 5 & $3($ 구) ; 1 (우) & - & - \\
\hline Ovary & 1 & 8 & - & - \\
\hline Cervix & 1 & 2 & - & - \\
\hline Prostate & 1 & $28(\widehat{\jmath})$ & - & - \\
\hline Colorectal & 0 & 23 (ふొ) ; 15 (우) & - & - (수); 34 (ㅇ) \\
\hline Lung & 0 & 70 (ฮ) ; 32 (ㅇ) & $160(\widehat{\jmath}) ; 133$ (†) & $68(\widehat{\jmath}) ; 55($ (ㅇ) \\
\hline $\begin{array}{c}\text { Total Number } \\
\text { of Cancer } \\
\text { Articles }^{\mathrm{a}}\end{array}$ & 56 & $230(\widehat{\jmath}) ; 149$ (†) & 356 (Љ̂) ; 253 () & $212($ Љૈ) ; 204 (†) \\
\hline
\end{tabular}

${ }^{\mathrm{a}}$ Includes all cancer articles (general cancer articles + specific cancer articles)

${ }^{\mathrm{b}}$ Actual age-standard mortality rates for Nunavut with $83.9 \%$ of population enumerated as Aboriginal.

${ }^{\mathrm{c}}$ Actual age-standardized mortality rates for Northwest Territories with $48.2 \%$ of population enumerated as Aboriginal (1996 Population Census, Statistics Canada http://www.statcan.ca/english/ Pgdb/People/Population/demo39a.htm).

Note: - indicates less than 5 cases per 100,000 population (mortality rate data from National Cancer Institute of Canada: Canadian Cancer Statistics, 2001). 
1996-2000. The coverage of cancer, by site, differed significantly from coverage expected by chance alone $\left(\chi_{\mathrm{df}(8)}^{2}=60.6, p<0.001\right)$. Of the articles each on cancer, $41 \%$ were on breast cancer, followed by $16 \%$ on leukemia/lymphoma, and $8.9 \%$ on melanoma. There were no articles on lung or colorectal cancers, and only one article each on prostate cancer and cervical cancer. Approximately one-quarter $(23 \%)$ of the articles focused on general cancer issues. Mobilizing information was found in articles on breast cancer (12/23) and leukemia/lymphomas (5/9). None of the other site specific cancers covered by the 14 First Nations newspapers surveyed between 1996-2000 included mobilizing information (i.e., ovarian, prostate, melanoma, cervical, multiple sites).

\section{Discussion}

The results of this survey of chronic disease coverage in Aboriginal newspapers in Canada indicate significantly greater volume of coverage on HIV/AIDS and diabetes relative to the volume of coverage on cancer and cardiovascular disease from 1996-2000. The number of articles on cardiovascular disease (including ischemic heart disease, hypertension, and stroke) accounted for only $7.5 \%$ of the total health coverage whereas coverage of HIV/AIDS captured $41.8 \%$ of the health articles. Population statistics for cardiovascular disease among Aboriginal peoples in Canada indicate that age-standardized prevalence rates are about three times higher than the non-Aboriginal Canadian population. Moreover, there are significantly higher mortality rates for Aboriginal women than the general non-Aboriginal population for both ischemic heart disease and stroke (Heart \& Stroke Foundation of Canada, 2000). In contrast, HIV prevalence in Canadian Aboriginal people is estimated at $5.5 \%$ of all prevalent HIV infections in Canada (Health Canada, 2000b) and HIV infection contributed $0.3 \%$ to the causes of death in Canada in 1997. According census statistics, the population percentage of Aboriginals is $3.7 \%$ of the Canadian population (Statcan, 1996). HIV/AIDS coverage represented over $40 \%$ of the health articles published between 1996-2000 in the Aboriginal newspapers surveyed.

Similar to cancer coverage in newspapers serving the non-Aboriginal population of Canada (MacDonald \& Hoffman-Goetz, 2001) and in magazines targeting U.S. racial/ ethnic minorities (Hoffman-Goetz, Gerlach, Marino, \& Mills, 1997), cancer coverage in Aboriginal newspapers was limited in number (56/400 articles) and did not reflect the leading causes of cancer death. Age-standardized lung cancer mortality was much higher in the two Canadian territories (Nunavut; Northwest Territories) with significant Aboriginal population. There are no public data which disaggregate cancer rates by race or ethnicity in Canada. However, these deaths are likely higher, i.e., reflecting the greater prevalence of smoking. It has been estimated that $60 \%$ of Canadian Aboriginal people use tobacco on a regular basis (Canadian Medical Association, 1996). Moreover, among American Indians and Alaska Natives the age-adjusted lung cancer death rates increased by $1.7 \%$ (males) and $2.9 \%$ (females) between 1990 and 1998 (Gargiullo, Wingo, Coates, \& Thompson, 2002). Alaska Natives had significantly elevated mortality rates for several smoking-related cancers (Ehrsam, Lanier, Holck, \& Sandidge, 2001). In light of this burden of lung cancer, the Assembly of First Nations of Canada identified an epidemic of tobacco misuse among First Nations youth and called for resources for smoking prevention, cessation, and treatment programs at the First Nations community level (Assembly of First Nations, 2003). At least some of these resources could involve dissemination through local community newspapers.

In contrast, the coverage of breast cancer was over-represented in the articles published in Canadian Aboriginal newspapers from 1996-2000 and accounted for over 40\% of cancer articles. This over-representation of breast cancer articles parallels the 
mainstream media (e.g., Hoffman-Goetz, Gerlach, Marino, \& Mills, 1997; Clarke, 1999). Traditionally breast cancer incidence and mortality rates have been low among the Inuit (Gaudette, Gao, Freitag, \& Wideman, 1993). Breast cancer incidence rates for American Indian women are also lower than for Hispanic women and non-Hispanic white women (Eidson, Becker, Wiggins, Key, \& Samet, 1994). It is not clear why the reporting of cancer in newspapers does not reflect the impact that specific cancers have on the mortality or incidence rates among Aboriginal peoples. There are, however, several factors, other than cancer statistics, which may influence the reporting in these newspapers.

One factor may be mainstream advocacy groups outside of ethnic culture. Breast cancer has powerful advocacy groups (e.g., Avon Flame Foundation, the Canadian Breast Cancer Foundation, and the Canadian Breast Cancer Network) that influence public discussion, public policy, and the research agenda. For example, the Canadian Breast Cancer Research Initiative has a mandate to "to establish and maintain an alliance of partners consisting of national businesses, not-for-profit agencies, government and the community, to generate the resources necessary to aggressively pursue this initiative, building upon and enhancing existing programs and facilities." (Canadian Breast Cancer Research Alliance). Part of the advocacy agenda involves targeting the mainstream media. This advocacy does not differentiate by ethnicity to a large extent and thus obfuscates the particular cultural and health issues of Aboriginals and other "minority" Canadians.

A second factor may be a spill-over or "contamination" from the non-Aboriginal media. Of the 23 articles on breast cancer, 8 were obtained from wire services or unnamed sources. Wire services typically provide information that is geared for the general population. Aside from wire service "influence", it appears that in part because of the lack of disaggregating statistics on ethnicity and health, the Aboriginal media mirrors the mainstream media in disease emphasis.

A third reason for the greater coverage on breast cancer may relate to agenda-setting by the media, a process whereby groups compete to identify issues, move the issues to the public agenda, and then link the issues with persuasive symbols (Finnegan \& Viswanath, 1997). Breast cancer is a powerful health issue that has political and social legitimacy in the larger population. By focusing on breast cancer, editors and reporters in the ethnic media could help to mobilize marginalized groups (e.g., First Nations women) around an issue that already has a strong voice and clearly recognized symbols in the mainstream press. Alternatively, agenda-setting on the topic of breast cancer could shift public perceptions about the leading causes of cancer death among Aboriginal peoples and reduce public discourse on the underlying determinants of these cancers (e.g., tobacco use with lung cancer, sexual violence and multiple sex partners with cervical cancer). Thus, understanding how health issues are constructed by the Aboriginal media will be an important area of future research if health information disparities are to be addressed in a meaningful way.

There was little mobilizing information accompanying articles in the Aboriginal newspapers. Slightly more than one-third $(36.5 \%)$ of the articles $(146 / 400)$ contained mobilizing information for which further details could be obtained. This finding supports research showing a general lack of mobilizing information in Canadian (MacDonald \& Hoffman-Goetz, 2001) and American newspapers (Freimuth, Greenburg, DeWitt, \& Romano, 1984) daily newspapers. Without the cues of mobilizing information, it may be difficult for individuals to be proactive and find ways to take charge of their health. Results from the present study also show that if articles contained mobilizing information, contact information was usually of a local nature $(77 \%)$ rather 
than distant or not specified $(8 \%)$. This may or may not be a problem. At times, referrals to local sources of help may be essentially "dead ends" because of the lack of sustained provision of health and social services in both remote and less remote Aboriginal communities.

Cancer and other chronic disease information is prevalent in Canada. Despite the overwhelming volume of health information available, minorities, individuals living in rural communities, and the poor are less knowledgeable about health promotion and disease prevention issues than the general population (Breslow, Sorkin, Frey, \& Kessler, 1997; Brownson \& Jackson-Thompson, 1992). Moreover, it appears that media information is not tailored to the epidemiologically documented health concerns of Aboriginal Canadians in a sustained way. Disparities in type and degree of exposure to health information may contribute to differences in health status (Benjamin-Garner et al., 2002). Yanovitzky \& Blitz (2000) found that media coverage of cancer issues was important for individuals without regular contact with health services; mass media and physician advice were seen to complement one another in facilitating mammography utilization.

The preferred channels for health information may vary by ethnicity and social class. Individuals with high school education were more likely to use newspapers as a source of health information than those with some college or post-secondary education; the use of print media for health information varied by race/ethnicity with white Americans, Hispanic Americans, and Asian/Pacific Islander/Native Americans ("other") reporting greater use than black Americans (Benjamin-Garner et al., 2002). Delivery of health information via the radio was effective for Spanish-speaking, less acculturated Hispanics (Gombeski et al., 1981). Little is known about the preferred channels of exposure to cancer and other health information among the First Nations, Métis, and Inuit.

There are potential biases in this study. Only Aboriginal newspapers available in English were included. It is possible that health information presented to Aboriginal peoples in languages other than English provides a more balanced coverage of disease risks. It is known that acculturation, "the process whereby the attitudes and/or behaviors of persons from one culture are modified as a result of contact with a different culture" (Moyerman \& Forman, 1992, p. 163), influences health and health behaviors of ethnic and cultural groups (Campbell \& Kaplan, 1997; Kahn, Sobal, \& Martorell, 1997). Culturally appropriate cancer information was associated with increased screening rates among non-English speaking minority women (Mitchell, Hirst, Mitchell, Staples, \& Torcello, 1997). It is not known if the type and quality of disease coverage in mass print media varies as a function of acculturation.

It is possible that other print media available to the First Nations, Inuit, and Métis described cancer and health issues to a greater extent than the newspapers included in this survey. It would be difficult to determine the extent to which these group are exposed to health and cancer articles published in media not aimed at native populations. Therefore, this analysis was limited to Aboriginal people's newspapers in an attempt to gauge the coverage of cancer and health issues directed specifically at this target readership.

Moreover, because only 14 Aboriginal newspapers were reviewed, other Aboriginal newspapers may have covered health issues to a greater extent than those included here. This study would then underestimate coverage of health and cancer in Aboriginal newspapers. An exhaustive review of all Aboriginal newspapers published in Canada would be extremely difficult to conduct since these ethnic media are not indexed in databases such as the Reader's Guide to Periodical Literature and are not available through archival sources.

This study has shown that the distribution of cancer and other chronic disease information in newspapers serving the Aboriginal peoples of Canada under-reports 
information about tobacco related diseases. Breast cancer was over-reported in newspapers despite lower population mortality for this disease compared with the nonAboriginal population and parallels the distribution of breast cancer coverage in the mainstream media. The lack of coverage on heart disease and lung cancer was striking given the prevalence of smoking and lung cancer among the First Nations, Métis, and Inuit peoples and the vigorous anti-tobacco legislation in Canada. These results strongly suggest the need for research on effective strategies to reduce health information disparities among minority populations. Greater and more balanced coverage of risks in the public press may contribute to an increase in Aboriginal people's awareness and, ultimately, knowledge of threats to their health. Nonetheless, in the absence of disaggregating statistics (by health and ethnicity), cultural and disease specific health promotion information will not be possible in the ethnic media.

\section{References}

Assembly of First Nations. (2003). First Nations health priorities. Available at http://www.afn.ca/ Programs/Health\%20Secretariat/health.htm

Benjamin-Garner, R., Oakes, J.M., Meischke, H., Meshack, A., Stone, E.J., Zapka, J., Finnegan, J.R., Jr., Wallace, L., Taylor, J., \& McGovern, P. (2002). Sociodemographic differences in exposure to health information. Ethnicity \& Disease, 12, 124-134.

Breslow, R.A., Sorkin, J.D., Frey, C.M., \& Kessler, L.G. (1997). Americans' knowledge of cancer risk and survival. Preventive Medicine, 26, 170-177.

Brownson, R.C., \& Jackson-Thompson, J. (1992). Demographic and socioeconomic differences in beliefs about the health effects of smoking. American Journal of Public Health 82, 99-103.

Burhansstipanov, L., \& Dresser, C. (1994). Documentation of the cancer research needs of American Indians and Alaska Natives. Native American Monograph No. 1. National Cancer Institute, N.I.H. Publication No. 94-3603.

Campbell, K., \& Kaplan, C. (1997). Relationship between language orientation and cigarette smoking beliefs of Latinas. American Journal of Health Behavior, 21, 1-20.

Canadian Breast Cancer Research Alliance. Goals and objecives. Available at: http:// www.breast.cancer.ca/about_cbcra/goals/

Canadian Medical Association. (1997). Tobacco and health. CMA Policy Summary. Canadian Medical Association Journal, 156, 240A-240C.

Clarke, J.N. (1999). Breast cancer in mass circulating magazines in the USA and Canada, 19741997. Women and Health, 28, 113-130.

Clift, E., \& Freimuth, V. (1995). Health communication: What is it and what can it do for you? Journal of Health Education, 26, 68-74.

Demay, J. (1993). The persistence and creativity of Canadian Aboriginal newspapers. Canadian Journal of Communication, on-line. Available: http://www.cjc-online.ca/toc_index. php3? = 12 journal

Durant, J.R., Evans, G.A., \& Thomas, G.P. (1989). The public understanding of science. Nature, $340,11-14$.

Ehrsam, G., Lanier, A., Holck, P., \& Sandidge, J. (2001). Cancer mortality among Alaska natives, 1994-1998. Alaska Medicine, 43, 50-60.

Eidson, M., Becker, T.M., Wiggins, C.L., Key, C.R., \& Samet, J.M. (1994). Breast cancer among Hispanics, American Indians and non-Hispanic whites in New Mexico. International Journal of Epidemiology, 23, 231-237.

Fink, R., Roeser, R., Venet, W., Strax, P., Venet, L., \& Lacher, M. (1978). Effects of news events on response to a breast cancer screening program. Public Health Reports, 93, 318-327.

Finnegan, J.R., \& Viswanath, K. (1997). In K. Glanz, F.M. Lewis, \& B. Rimer (Eds.) Health Behavior and Health Education. $2^{\text {nd }}$ Edition. Jossey-Bass Publishers, San Francisco, pp. 313341. 
Freimuth, V.S., Greenburg, R.H., DeWitt, J., \& Romano, R.M. (1984). Covering cancer: Newspapers and the public interest. Journal of Communication, Winter, 62-73.

Frewer, L.J., \& Shepard, R. (1994). Attributing information to different sources: Effects on the perceived qualities of information, on the perceived relevance of information, and on attitude formation. Public Understanding of Science, 3, 385-401.

Gargiullo, P., Wingo, P.A., Coates, R.J., \& Thompson, T.D. (2002). Recent trends in mortality rates for four major cancers, by sex and race/ethnicity-United States, 1990-1998. MMWR, 51, 4953.

Gaudette, L.A., Gao, R.-N., Freitag, S., \& Wideman, M. (1993). Cancer incidence by ethnic group in the Northwest Territories (NWT) in 1969-1988. Health Reports, 5, 23-32.

Gerlach, K.K., Marino, C., \& Hoffman-Goetz, L. (1997). Cancer coverage in women's magazines: What information are women receiving? Journal of Cancer Education, 12, 240-244.

Gombeski, W.R., Moore, T.J., Contant, C.F., Ramirez, A.G., Farge, E.J., \& Kautz, J.A. (1981). Health information of the poorly informed: Implications for health educators and communicators. Health Values, 5, 199-206.

Gottlieb, N. (2001). The age of breast cancer awareness: What is the effect of media coverage? The Journal of the National Cancer Institute, 93, 1520-1522.

Health Canada. (2000a). Diabetes among Aboriginal people in Canada: The evidence. Available: http://www.hc-sc.gc.calfnihb-dgspni/fnihb/chp/adi/index.htm

Health Canada. (2000b). National trends of AIDS and HIV in Canada. Canada Communicable Disease Report 2000; 26-23. Available: http://www.hc-sc.gc.ca/hpb/lcdc/publicat/ccdr/ 00vol26/dr2623ea.html

Heart \& Stroke Foundation of Canada. (2000). The changing face of heart disease and stoke in Canada, 2000. Available: http://www.hc-sc.gc.ca/hpb/lcdc/bcrdd/hdsc2000/

Hoffman-Goetz, L., Gerlach, K, K., Marino, C., \& Mills, S.L. (1997). Cancer coverage and tobacco advertising in African-American women's popular magazines. Journal of Community Health, $22,261-270$.

Hoffman-Goetz, L., \& MacDonald, M. (1999). Cancer coverage in mass-circulating Canadian women's magazines. Canadian Journal of Public Health, 90, 55-59.

Hofstetter, C.R., Schultze, W.A., \& Mulvihill, M.M. (1992). Communications media, public health, and public affairs: Exposure in a multimedia community. Health Communication, 4, 259-271.

James, C., James, N., Davies, D., Harvey, P., \& Tweddle, S. (1999). Preferences for different sources of information about cancer. Patient Education and Counseling, 37, 273-282.

Johnson, J.D., \& Meischke, H. (1991). Women's preferences for cancer information from specific communication channels. American Behavioral Scientist, 34, 742-755.

Kahn, L.K., Sobal, J., \& Martorell, R. (1997). Acculturation, socioeconomic status, and obesity in Mexican Americans, Cuban Americans, and Puerto Ricans. International Journal of Obesity Related Metabolic Disorders, 21, 91-96.

MacDonald, M., \& Hoffman-Goetz, L. (2001). Cancer coverage in newspapers serving large and small communities in Ontario. Canadian Journal of Public Health, 92, 372-375.

MacMillan, H., MacMillan, A., Offord, D., \& Dingle, J.L. (1996). Aboriginal health. Canadian Medical Association Journal, 155, 1569-1578.

Miller, M.G., \& Millar, K.U. (1998). The influence of informational and performance messages on intentions to perform health behaviors. Psychology, Health \& Medicine, 3, 243-252.

Mitchell, H., Hirst, S., Mitchell, J.A., Staples, M., \& Torcello, N. (1997). Effect of ethnic media on cervical cancer screening rates. Australian and New Zealand Journal of Public Health, 21, 265-267.

Moyerman, D.R., \& Forman, B.D. (1992). Acculturation and adjustment: A meta-analytic study. Hispanic Journal of Behavioral Science, 14, 163-2000.

Statcan. (1996). Canadian statistics-Total population by Aboriginal group, 1996. Available: http:// www.statcan.ca/english.Pgdb/People/Population/demo39a.htm.

WUNSKA and SIFC (First Nations Social Research Institute of the Saskatchewan Indian Federated College). (1997). First Nations youth inquiry into tobacco use: Final comprehensive report to Health Canada, April 1997. 
Yanovitzky, I., \& Blitz, C.L. (2000). Effect of media coverage and physician advice on utilization of breast cancer screening by women 40 years and older. Journal of Health Communication, 5 , $117-134$.

Young, T.K. (1993). Diabetes mellitus among Native Americans in Canada and the United States: An epidemiological review. American Journal of Human Biology, 5, 399-413.

Young, T.K., Moffatt, M.E.K., \& O'Neil, J.D. (1993). Cardiovascular diseases in a Canadian arctic population. American Journal of Public Health, 83, 881-887. 